\title{
NOTE ON INCOME TAXATION AND OCCUPATIONAL CHOICE
}

\author{
EYTAN SHESHINSKI
}

CESIFo WORKING PAPER No. 880

CATEgory 1: Public FinANCE

FEBRUARY 2003

\footnotetext{
An electronic version of the paper may be downloaded

- from the SSRN website: www.SSRN.com

- from the CESifo website: www.CESifo.de
} 


\title{
NOTE ON INCOME TAXATION AND OCCUPATIONAL CHOICE
}

\begin{abstract}
With varying aptitudes in different occupations, individuals typically maximize income by specializing in one occupation which promises the highest income. Due to numerous labor market imperfections and uncertainties, the choice of best occupation is accomplished with only partial success. We demonstrate that an income tax that reduces after-tax income differentials across occupations tends to exacerbate the errors of choice made by individuals. Following a model proposed by Tinbergen (1951) and developed by Houthakker (1974), we use Luce's (1959) multinominal logit approach to evaluate the magnitude of the distortions due to errors in occupational choice caused by income taxation. In an example, we show that the deadweight loss can be as high as a third of total income.
\end{abstract}

JEL Code: D3, H0, J2.

Keywords: distribution of aptitudes, size distribution of income, logit model.

\author{
Eytan Sheshinski \\ Department of Economics \\ The Hebrew University of Jerusalem \\ Mount Scopus \\ Jerusalem 91905 \\ Israel \\ mseytan@mscc.huji.ac.il
}




\section{Introduction}

With varying aptitudes in different occupations, individuals typically maximize income by specializing in one occupation which promises the highest income. Due to numerous labor market imperfections and uncertainties, this is accomplished with only partial success. We demonstrate that an income tax that reduces the after-tax income differentials across occupations tends to exacerbate the errors of choice made by individuals.

Following a model proposed by Tinbergen (1951) and developed by Houthakker $(1974)^{1}$, we use Luce's (1959) multinominal logit approach to evaluate the magnitude of the distortions caused by income taxation. In an illustration with a specific example, we show that at high marginal tax rates these distortions can be in excess of a third of mean income.

\footnotetext{
${ }^{1}$ A related paper is Sheshinski (1983)
} 


\section{An Occupational Choice Model}

Individuals are endowed with aptitudes in different occupations. These aptitudes are represented by a vector $\left(y_{1}, y_{2}, \ldots, y_{n}\right)$, where $y_{i}(\geq 0)$ is the value of the $i$-th commodity that the individual could produce in a given time period if he/she did nothing else. Since the $y_{i}$ 's are constants and all individuals have a given working time, value maximization implies that each individual will work all the time on the occupation for which $y_{i}$ is greatest. Generally, there is only one such occupation. If there is more than one, the allocation is indeterminate.

In view of the many imperfections in the labor market, it is unrealistic to assume perfect income maximization. We shall follow the approach suggested by Luce (1959), that individuals maximize "imperfectly", the probability of choosing occupation $i, p_{i}$, being given by

$$
p_{i}=p_{i}\left(y_{1}, y_{2}, \ldots, y_{n}\right)=\frac{e^{q y_{i}}}{\sum_{j=1}^{n} e^{q y_{i}}}, \quad i=1,2, \ldots, n
$$

where $q$ is a positive constant, representing the 'precision' of choice. As $q \rightarrow \infty$, the probability $p_{i}$ increases monotonically, approaching 1 if $y_{i}=\arg \max \left(y_{1}, y_{2}, \ldots, y_{n}\right)$ and decreases monotonically, approaching 0 , otherwise. At the other end, as $q \rightarrow 0, p_{i}$ approaches $\frac{1}{n}$ which means that all occupations have an equal probability of being chosen, irrespective of individual aptitudes. It is natural to call $q$ the "degree of rationality" $(q=\infty$, "perfect rationality"). 
Assume that the aptitude vector $\left(y_{1}, y_{2}, \ldots, y_{n}\right)$ varies randomly over the population with a continuous density function $f\left(y_{1}, y_{2}, \ldots, y_{n}\right)$. The distribution function $F\left(y_{1}, y_{2}, \ldots, y_{n}\right)$ is then also continuous (and differentiable). The marginal density functions in different occupations need not be independent.

Let $G(z)$ be the cumulative distribution function for labor incomes, and $g(z)$ the corresponding density function. It is seen that:

$$
\begin{gathered}
G(z)= \\
=\sum_{i=1}^{n} \int_{0}^{\infty} \ldots \int_{0}^{z} \ldots \int_{0}^{\infty} p_{i}\left(y_{1}, \ldots y_{i-1}, x, y_{i+1}, . ., y_{n}\right) f\left(y_{1}, \ldots y_{i-1}, x, y_{i+1}, . ., y_{n}\right) \\
d y_{1} \ldots d y_{i-1} d x d y_{i+1} \ldots d y_{n}
\end{gathered}
$$

In subsequent discussion it will suffice to examine the case $n=2$. For this case, (2) is written

$$
\begin{aligned}
G(z)= & \int_{0}^{z} \int_{0}^{\infty} p_{1}\left(y_{1}, y_{2}\right) f\left(y_{1}, y_{2}\right) d y_{1} d y_{2} \\
& +\int_{0}^{\infty} \int_{0}^{z} p_{2}\left(y_{1}, y_{2}\right) f\left(y_{1}, x\right) d y_{1} d y_{2} \\
& =\int_{0}^{z} \int_{0}^{\infty} \frac{e^{q y_{1}}}{e^{q y_{1}}+e^{q y_{2}}} f\left(y_{1}, y_{2}\right) d y_{1} d y_{2} \\
& +\int_{0}^{\infty} \int_{0}^{z} \frac{e^{q y_{2}}}{e^{q y_{1}}+e^{q y_{2}}} f\left(y_{1}, y_{2}\right) d y_{1} d y_{2}
\end{aligned}
$$




\section{An Example}

Consider the bivariate exponential density function ${ }^{2}$

$$
f\left(y_{1}, y_{2}\right)=\alpha_{1} \alpha_{2} e^{-\alpha_{1} y_{1}-\alpha_{2} y_{2}}
$$

and the corresponding distribution function

$$
F\left(y_{1}, y_{2}\right)=\left(1-e^{-\alpha_{1} y_{1}}\right)\left(1-e^{-\alpha_{2} y_{2}}\right)
$$

\section{(a) Perfect Rationality}

When $q=\infty, p_{i}\left(y_{1}, y_{2}\right)$ is 1 when $y_{i} \geq y_{j}, i, j=1,2$ and 0 otherwise. Hence, by (3) and (4),

$$
\begin{aligned}
G(z)_{q=\infty}= & \alpha_{1} \alpha_{2} \int_{0}^{z} \int_{0}^{y_{1}} e^{-\alpha_{1} y_{1}-\alpha_{2} y_{2}} d y_{1} d y_{2} \\
& +\alpha_{1} \alpha_{2} \int_{0}^{z} \int_{0}^{y_{2}} e^{-\alpha_{1} y_{1}-\alpha_{2} y_{2}} d y_{1} d y_{2} \\
& =\left(1-e^{-\alpha_{1} z}\right)\left(1-e^{-\alpha_{2} z}\right) \\
& =F(z, z)
\end{aligned}
$$

The corresponding density function

$$
g(z)_{q=\infty}=\alpha_{1} e^{-\alpha_{1} z}+\alpha_{2} e^{-\alpha_{2} z}-\left(\alpha_{1}+\alpha_{2}\right) e^{-\left(\alpha_{1}+\alpha_{2}\right) z}
$$

has an interior mode and positive skewed shape as observed in empirical income distributions.

\footnotetext{
${ }^{2}$ This is the product of two univariate distributions. While not allowing for dependence, this is a simple illustrative case that has zero probability of ties (see below).
} 
Expected income, $\bar{y}_{q=\infty}$, is

$$
\bar{y}_{q=\infty}=\frac{1}{\alpha_{1}}+\frac{1}{\alpha_{2}}-\frac{1}{\alpha_{1}+\alpha_{2}}
$$

\section{(b) Uniformly Random Choice}

At the other extreme, when $q=0, p_{i}\left(y_{1}, y_{2}\right)=\frac{1}{2}$ independent of $\left(y_{1}, y_{2}\right)$. By (3) and (4),

$$
G(z)_{q=0}=1-\frac{1}{2}\left(e^{-\alpha_{1} z}+e^{-\alpha_{2} z}\right)
$$

The corresponding density is

$$
g(z)_{q=0}=\frac{1}{2}\left(\alpha_{1} e^{-\alpha_{1} z}+\alpha_{2} e^{-\alpha_{2} z}\right)
$$

which, as expected, is the arithmetic mean of two univariate densities.

Mean income, $\bar{y}_{q=0}$, is now

$$
\bar{y}_{q=0}=\frac{1}{2}\left(\frac{1}{\alpha_{1}}+\frac{1}{\alpha_{2}}\right) .
$$

It is not surprising that maximization of income by individuals leads to a larger mean income than when individuals choose occupations randomly ${ }^{3}$ :

\footnotetext{
${ }^{3}$ The variances in these two cases are $\sigma_{q=\infty}^{2}=\frac{1}{\alpha_{1}^{2}}+\frac{1}{\alpha_{2}^{2}}-\frac{3}{\left(\alpha_{1}+\alpha_{2}\right)}$, and $\sigma_{q=0}^{2}=$ $\frac{3}{4}\left(\frac{1}{\alpha_{1}^{2}}+\frac{1}{\alpha_{2}^{2}}\right)-\frac{1}{2 \alpha_{1} \alpha_{2}}$. The sign of the difference between these variances depends on parameter values.
} 


$$
\bar{y}_{q=\infty}-\bar{y}_{q=0}=\frac{1}{2}\left(\frac{1}{\alpha_{1}}+\frac{1}{\alpha_{2}}\right)-\frac{1}{\alpha_{1}+\alpha_{2}}>0 .
$$

The relative loss of income can be quite substantial. For illustration, take $\alpha_{1}=.01$ and $\alpha_{2}=.02$ (corresponding to mean abilities of 100 and 50, respectively). For these parameter values, the relative loss exceeds 36 percent of income!

It can be shown that the distribution function $G_{q=\infty}(z)$ stochastically dominates (in the 'first-degree') the distribution $G_{q=0}(z)^{4}$. That is, for any concave utility function, social welfare is higher under perfect rationality.

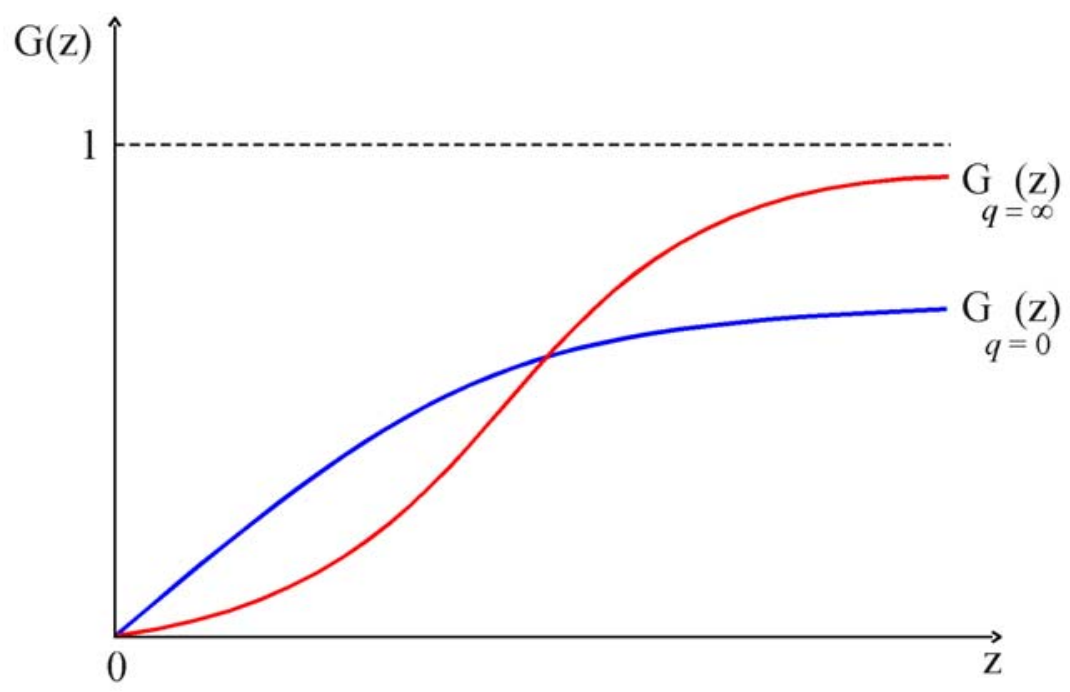

Figure 1

Calculations for intermediate cases, $0<q<\infty$, turn out to be complex, yielding no explicit analytic solutions.

\footnotetext{
${ }^{4} G_{q=\infty}(z)$ and $G_{q=0}(z)$ intersect once, with $G_{q=\infty}(z)$ steeper at the intersection point.
} 


\section{Effect of An Income Tax}

The effect of a progressive income tax on mean income is the same as the effect of a reduction in the degree of rationality, $q$. For simplicity, suppose there is in place a linear income tax function $t(z)=-a+(1-b) z$, where the support level $a, a>0$, and the after-tax rate $b, 0<b<1$, are constants and $z$ is before-tax income. After-tax income is $z-t(z)=a+b z$. The probabilities of individual choice, (1), now depend on after-tax income:

$$
p_{i}=\frac{e^{q\left(a+b y_{i}\right)}}{\sum_{j=1}^{n} e^{q\left(a+b y_{j}\right)}}=\frac{e^{q b y_{i}}}{\sum_{j=1}^{n} e^{q b y_{j}}} \quad i=1,2, \ldots, n
$$

It is seen that $q$ and $b$ (the after-tax rate) are interchangeable. Except in the polar cases $q=\infty$ and $q=0$, the marginal tax rate affects occupational choice and hence entails a deadweight loss in terms of mean income. We have seen before that this effect can be significant. Of course, more detailed calculations for alternative levels of $q$ are required in order to evaluate the effect of marginal tax increases and a corresponding increase in the support level on mean income and on the distribution of after-tax incomes. 


\section{References}

[1] Houthakker, H. (1974), "The Size Distribution of Labor Incomes Derived From the Distribution of Aptitudes" in W. Sellekaerts. (ed.) Econometrics and Economic Theory.

[2] Luce, D. (1959), Individual Choice Behavior: A Theoretical Analysis (Wiley).

[3] Sheshinski, E. (1983), "Wage Policy in the Public Sector abd Income Distribution" Helpman, E., A. Razin and E. Sadka (eds.) Social Policy Evaluation: An Economic Perspective (Academic Press), 299-309.

[4] Tinbergen, J. (1951) "Some Remarks om the Distribution of Labor Incomes", International Economic Papers, 195-207. 


\title{
CESifo Working Paper Series
}

\author{
(for full list see www.cesifo.de)
}

815 Rainer Niemann and Dirk Simons, Costs, Benefits, and Tax-induced Distortions of Stock Option Plans, December 2002

816 Jan-Egbert Sturm and Barry Williams, Deregulation, Entry of Foreign Banks and Bank Efficiency in Australia, December 2002

817 V. Anton Muscatelli, Patrizio Tirelli, and Carmine Trecroci, Monetary and Fiscal Policy Interactions over the Cycle: Some Empirical Evidence, December 2002

818 Claude Hillinger, A General Theory of Price and Quantity Aggregation and Welfare Measurement, December 2002

819 Erkki Koskela and Ronnie Schöb, Optimal Capital Taxation in Economies with Unionised and Competitive Labour Markets, December 2002

820 Sheilagh Ogilvie, Guilds, Efficiency, and Social Capital: Evidence from German ProtoIndustry, December 2002

821 Hans Gersbach and Verena Liessem, Financing Democracy, December 2002

822 Costas Hadjiyiannis, Panos Hatzipanayotou, and Michael S. Michael, Optimal Tax Policies with Private-Public Clean-Up, Cross-Border Pollution and Capital Mobility, December 2002

823 François Ortalo-Magné and Sven Rady, Homeownership: Low Household Mobility, Volatile Housing Prices, High Income Dispersion, December 2002

824 Syed M. Ahsan and Panagiotis Tsigaris, Measuring the Social Discount Rate under Uncertainty: A Methodology and Application, December 2002

825 Kai A. Konrad, Altruism and Envy in Contests: An Evolutionarily Stable Symbiosis, December 2002

826 Robert S. Chirinko and Huntley Schaller, A Revealed Preference Approach to Understanding Corporate Governance Problems: Evidence from Canada, December 2002

827 Geir B. Asheim, Green National Accounting for Welfare and Sustainability: A Taxonomy of Assumptions and Results, December 2002

828 Andrea Gebauer, Chang Woon Nam, and Rüdiger Parsche, Lessons of the 1999 Abolition of Intra-EU Duty Free Sales for Eastern European EU Candidates, December 2002 
829 Giacomo Corneo, Work and Television, December 2002

830 Vivek H. Dehejia and Yiagadeesen Samy, Trade and Labour Standards - Theory, New Empirical Evidence, and Policy Implications, December 2002

831 Geir B. Asheim and Wolfgang Buchholz, A General Approach to Welfare Measurement through National Income Accounting, December 2002

832 Aaron Tornell and Frank Westermann, The Credit Channel in Middle Income Countries, January 2003

833 Gebhard Flaig, Time Series Properties of the German Monthly Production Index, January 2003

834 Campbell Leith and Jim Malley, Estimated Open Economy New Keynesian Phillips Curves for the G7, January 2003

835 Burkhard Heer and Bernd Süssmuth, Inflation and Wealth Distribution, January 2003

836 Erkki Koskela and Leopold von Thadden, Optimal Factor Taxation under Wage Bargaining - A Dynamic Perspective, January 2003

837 Carola Grün and Stephan Klasen, Growth, Income Distribution, and Well-Being: Comparisons across Space and Time, January 2003

838 Robert S. Chirinko and Ulf von Kalckreuth, On the German Monetary Transmission Mechanism: Interest Rate and Credit Channels for Investment Spending, January 2003

839 Sascha O. Becker, Andrea Ichino, and Giovanni Peri, How Large is the "Brain Drain" from Italy?”, January 2003

840 Albert Berry and John Serieux, All About the Giants: Probing the Influences on Growth and Income Inequality at the End of the $20^{\text {th }}$ Century, January 2003

841 Robert Fenge and Martin Werding, Ageing and the Tax Implied in Public Pension Schemes: Simulations for Selected OECD Countries, January 2003

842 Robert Fenge and Martin Werding, Ageing and Fiscal Imbalances Across Generations: Concepts of Measurement, January 2003

843 Giovanni Andrea Cornia, The Impact of Liberalisation and Globalisation on Income Inequality in Developing and Transitional Economies, January 2003

844 Peter Fredriksson and Per Johansson, Program Evaluation and Random Program Starts, January 2003

845 Bernd Hayo and Matthias Wrede, Fiscal Equalisation: Principles and an Application to the European Union, January 2003

846 Syed M. Ahsan and Jaideep Oberoi, Inequality, Well-being and Institutions in Latin America and the Caribbean, January 2003 
847 Chang Woon Nam and Doina Maria Radulescu, The Role of Tax Depreciation for Investment Decisions: A Comparison of European Transition Countries, January 2003

848 V. Bhaskar and Steinar Holden, Wage Differentiation via Subsidised General Training, January 2003

849 Paloma Lopez-Garcia, Labour Market Performance and Start-up Costs: OECD Evidence, January 2003

850 Christian Keuschnigg and Soren Bo Nielsen, Public Policy for Start-up Entrepreneurship with Venture Capital and Bank Finance, January 2003

851 Yin-Wong Cheung, Menzie D. Chinn, and Eiji Fujii, China, Hong Kong, and Taiwan: A Quantitative Assessment of Real and Financial Integration, January 2003

852 Gregory D. Hess, The Economic Welfare Cost of Conflict: An Empirical Assessment, February 2003

853 Douglas J. Cumming and Jeffrey G. MacIntosh, Comparative Venture Capital Governance. Private versus Labour Sponsored Venture Capital Funds, February 2003

854 Eckhard Janeba and John Douglas Wilson, Decentralization and International Tax Competition, February 2003

855 Tapio Palokangas, Capital Accumulation and Employment Cycles in a Model of Creative Destruction, February 2003

856 Brendan Walsh, When Unemployment Disappears: Ireland in the 1990s, February 2003

857 Luis H. R. Alvarez and Erkki Koskela, A General Approach to the Stochastic Rotation Problem with Amenity Valuation, February 2003

858 Christian Schultz, Strategic Campaigns and Redistributive Politics, February 2003

859 Ernst Fehr and Joseph Henrich, Is Strong Reciprocity a Maladaptation? On the Evolutionary Foundations of Human Altruism, February 2003

860 Haizhou Huang, Dalia Marin, and Chenggang Xu, Financial Crisis, Economic Recovery and Banking Development in Former Soviet Union Economies, February 2003

861 Pedro Cardoso and Bernard M.S. van Praag, How Sustainable Are Old-age Pensions in a Shrinking Population with Endogenous Labour Supply?, February 2003

862 Volker Meier, Efficient Transfer of Aging Provisions in Private Health Insurance, February 2003

863 Edward Castronova, Theory of the Avatar, February 2003 
864 Robert S. Chirinko, Hans van Ees, Harry Garretsen, and Elmer Sterken, Investor Protections and Concentrated Ownership: Assessing Corporate Control Mechanisms in the Netherlands, February 2003

865 Bernard M.S. van Praag and Pedro Cardoso, The Mix Between Pay-as-you-go and Funded Pensions and what Demography has to do with it, February 2003

866 Ernst Fehr, Urs Fischbacher, Bernhard von Rosenbladt, Jürgen Schupp, and Gert G. Wagner, A Nation-Wide Laboratory. Examining Trust and Trustworthiness by Integrating Behavioral Experiments into Representative Survey, February 2003

867 Frank Heinemann, The Inflationary Impact of Wage Indexation, February 2003

868 Eytan Sheshinski, Bounded Rationality and Socially Optimal Limits on Choice in a Self-Selection Model, February 2003

869 M. Hashem Pesaran, Estimation and Inference in Large Heterogenous Panels with Cross Section Dependence, February 2003

870 Luis H. R. Alvarez and Erkki Koskela, On the Tree-Cutting Problem under Interest Rate and Forest Value Uncertainty, February 2003

871 Norbert Berthold and Rainer Fehn, Unemployment in Germany: Reasons and Remedies, February 2003

872 Clemens Fuest, Bernd Huber, and Philipp Tilleßen, Tax Policy and Entrepreneurship in the Presence of Asymmetric Information in Capital Markets, February 2003

873 Eytan Sheshinski, Optimum and Risk-Class Pricing of Annuities, February 2003

874 Willi Leibfritz, Paul O'Brien and Jean-Christophe Dumont, Effects of Immigration on Labour Markets and Government Budgets - An Overview, February 2003

875 M. Hashem Pesaran and Allan Timmermann, How Costly is it to Ignore Breaks when Forecasting the Direction of a Time Series?, February 2003

876 Thorvaldur Gylfason and Gylfi Zoega, Education, Social Equality and Economic Growth: A View of the Landscape, February 2003

877 Robin Boadway and Jean-François Tremblay, Public Economics and Startup Entrepreneurs, February 2003

878 Erkki Koskela and Roope Uusitalo, The Un-Intended Convergence: How the Finnish Unemployment Reached the European Level, February 2003

879 Robert Fenge and Volker Meier, Pensions and Fertility Incentives, February 2003

880 Eytan Sheshinski, Note on Income Taxation and Occupational Choice, February 2003 